\title{
TIDAL TRIGGERING OF EARTHQUAKES
}

\author{
By Thomas H. Heaton
}

\begin{abstract}
Analysis of the tidal stress tensor at the time of moderate to large earthquakes fails to confirm an earlier hypothesis that the origin times of shallow dip-slip earthquakes correlate with solid-earth tidal shear stress. Furthermore, no correlation is seen for either tidal shear stress or tidal normal-to-the-fault compressive stress with shallow strike-slip earthquakes or with deep earthquakes.
\end{abstract}

\section{INTRODUCTION}

In an earlier study (Heaton, 1975), I reported on the results of an investigation that suggested a correlation between the origin times of moderate to large shallow dip-slip earthquakes and tidal shear stress as resolved into a coordinate frame defined by the slip vectors of individual earthquakes. In that investigation, I computed the solid earth tidal shear stress for 107 earthquakes for which the focal mechanisms were known. Although no significant tidal correlation was found for the entire data set, which contained earthquakes of all depths and mechanisms, a fairly striking correlation was seen for those 34 earthquakes that were classified as shallow dip-slip earthquakes. Because of that result, I concluded that there is good reason to believe that larger shallow dip-slip earthquakes are tidally triggered. In order to test the validity of that hypothesis, in this study I calculate tidal stress histories for 222 earthquakes that were not considered in the previous study. Of these, 68 are classified as shallow dip-slip. If the previous hypothesis is to be considered physically meaningful, then a similar correlation between tidal shear stress history and the origin times of earthquakes should be seen for this new data set. The purpose of this study, then, is to confirm or reject the hypothesis that the origin times of shallow dip-slip earthquakes correlate with tidal shear stress.

As geophysical problems go, the problem solved in this paper is very well posed. That is, there are very few subjective judgments which must be made. Both the way in which the data are chosen and the method of statistical analysis are defined by the earlier study. Having well-defined rules is essential if statistics are to have meaning. Furthermore, the statistics are invalid if results are examined before deciding whether to play the game. This is a common problem with many earthquake prediction statistical studies and one which I seem to have poorly understood in my earlier study (Heaton, 1975). However, it seems clear that professional casinos would not allow their patrons to make this same mistake.

\section{EARTHQUAKES AND TIDES}

In this study, a very simple earthquake tidal triggering mechanism for earthquakes is tested. That is, do earthquakes occur preferentially at times when solid earth tides increase the shear stress on faults? In order to answer this question, the solid body tidal stress is computed as a function of time and then rotated into the coordinate frame which is defined by the earthquake fault plane and the slip vector. In this way, the tidal shear stress that can be considered to be sympathetic to failure can be plotted as a function of time. The coordinate frame that is used in this study is illustrated in Figure 1. The procedure used for calculating the solid earth tidal stress is described by Heaton (1975) and identical computer codes are used in both 
these studies. In addition to calculating the shear stress, the normal-to-the-fault compressive tidal stress, and the hydrostatic stress $\left(\tau_{11}+\tau_{22}+\tau_{33}\right) / 3$ are also computed for each earthquake. The fault plane and slip vector of each earthquake are defined from published source studies. Due to the symmetry of the stress tensor, either of the two complementary fault planes and slip vectors that are obtained from focal-mechanism studies can be used to specify the coordinate frame into which the tidal stress tensor is rotated.

The effects of oceanic tides on crustal stress are ignored in this study. This is not to imply that oceanic tides are unimportant. On the contrary, oceanic tidal stress can cause significant pertubations in the phase and amplitude of crustal tidal stress and in some instances may dominate over the solid earth tidal stress (Beaumont and Berger, 1975). Unfortunately, computation of tidal stress due to oceanic loading is quite difficult and beyond the scope of this study. Because of the statistical nature of this problem, one may argue that inclusion of the contribution of oceanic tides is

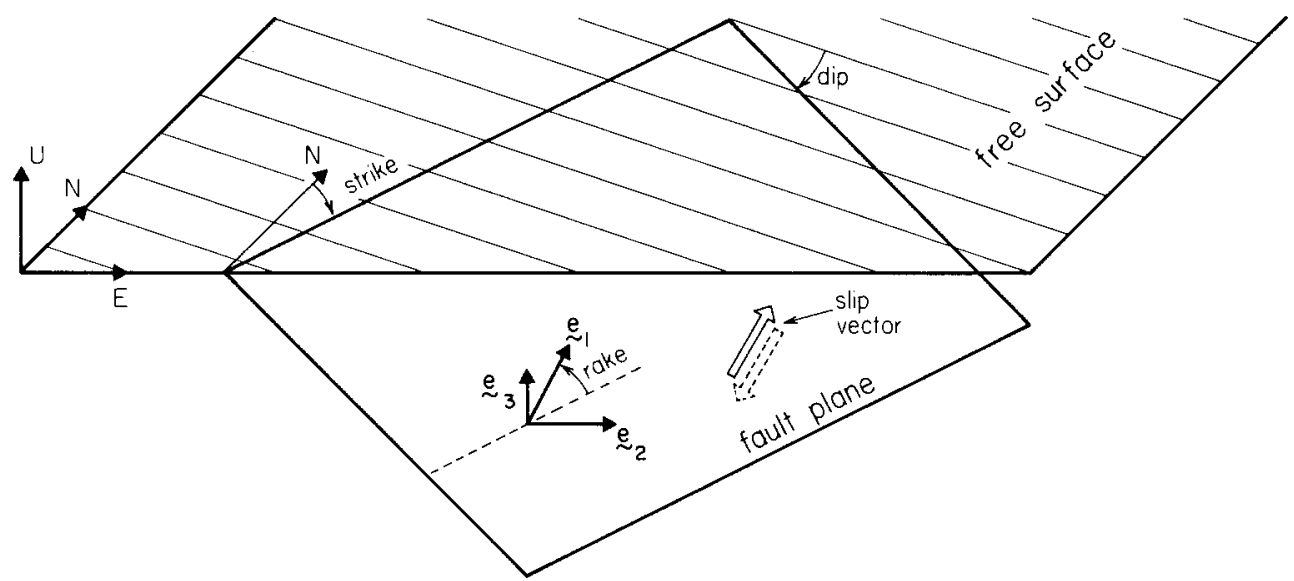

FIG. 1. Coordinate system used in this report. Fault strike is defined as clockwise from north. Dip is positive for a fault striking north and dipping east. Rake is $0^{\circ}$ for left-lateral and positive $90^{\circ}$ for thrust. $e_{1}$ is alined parallel to the slip vector and $e_{3}$ is perpendicular to the fault.

not crucial for this test of tidal triggering. Nevertheless, it is clear that modeling the contribution of oceanic loading is desirable.

\section{Choice of Data SeT}

The purpose of this study is to determine whether the origin times of earthquakes depend upon tidal stress. Thus, it seems clear that only earthquakes whose origin time is independent of other obvious factors should be chosen. Therefore, an attempt was made to include only earthquakes that were main shocks and that were not preceded by obvious large foreshock activity. Furthermore, the fault plane and slip vector for each earthquake should be known and well constrained. These parameters were obtained from either observed surface rupture or seismically determined faultplane solutions. Because of the free-surface boundary condition, $\tau_{31}$ (the shear stress sympathetic to failure) for dip-slip earthquakes on vertical faults is always nearly zero. The polarity of the computed tidal shear stress for dip-slip earthquakes on nearly vertical faults is thus sensitive to minor errors in the fault-plane solution. Therefore, earthquakes with dip-slip motion on near-vertical faults are excluded. Earthquakes that appear to meet the specifications listed above were rather ran- 
domly chosen from a variety of sources. The earthquakes were then classified according to focal depth and mechanism. They are listed in chronological order in Tables 1 to 3 . Entries with an asterisk represent earthquakes that were considered in my earlier study (Heaton, 1975). Earthquakes with slip angles of less than $30^{\circ}$ from horizontal are classified as strike-slip and earthquakes with depths greater than $30 \mathrm{~km}$ are considered as deep. However, since a focal depth of $33 \mathrm{~km}$ is often used as a default value in published catalogs, some of the earthquakes that are called deep may have actually been significantly shallower. To protect against systematic error due to my own predjudices (i.e., a desire to repeat my previous results), the decisions were made about earthquake parameters before any tides were computed and the decisions were final.

\section{Data Analysis}

The data analysis in this study is identical to that in my earlier study (Heaton, 1975). Tidal stresses are plotted as a function of time for each earthquake. A phase is then assigned using a linear scale (with time) from $0^{\circ}$ to $360^{\circ}$, where $0^{\circ}$ and $360^{\circ}$ are defined by the times of tidal stress maxima immediately before and after the earthquake, respectively (see Figure 2). These phases are then plotted on rose diagrams. If earthquake origin times and tidal stress are independent, then the phases will appear uniformly distributed about the rose diagram. Clustering of the phases on one side of a rose diagram indicates a possible relationship between tides and earthquakes. The statistical significance of clustering is evaluated by a clever and simple method developed by Rayleigh (1919). Consider a random walk in two dimensions (see Figure 3). Let each earthquake phase $\zeta_{i}$ represent a unit step in the $\zeta_{i}$ direction. If the magnitude of the vector sum of $m$ unit two-dimensional vectors $\left(1, \zeta_{i}\right)$ is denoted by $R$, then the probability $P_{R}$ that a random set of $m$ phases will produce a vector sum whose magnitude exceeds $R$ is approximately equal to $\exp \left(-R^{2} / m\right)$. This approximation is sufficient when $m$ is larger than 10 . Thus, the smaller is $P_{R}$, the greater becomes our confidence in tidal triggering.

\section{RESUlts}

The results of this study are summarized in Tables 1 to 3 and Figures 4 and 5 . Phases of the hydrostatic stress, normal-to-the-fault compressive stress, and shear stress are given for each earthquake. Zero degrees phase denotes either maximum tensile or maximum shear stress. Figure 5, a and b, shows no apparent correlation between earthquake origin times and tidal shear stress or normal-to-the-fault compressive stress for the entire data set (328 earthquakes). The same conclusion is reached when only those earthquakes deeper than $30 \mathrm{~km}$ are considered (Figure 5 , c and d). If the data set is restricted to shallow (depth $<30 \mathrm{~km}$ ) strike-slip (slip vector $<30^{\circ}$ from horizontal) earthquakes, then no apparent correlation can be seen for either shear stress or normal-to-the-fault compressive stress (Figure 5, a and b). All of the above results are compatible with my earlier study (Heaton, 1975). In that earlier study, however, there was a rather striking correlation between the origin times and tidal shear stress seen for shallow dip-slip earthquakes (34 events). An additional 68 shallow dip-slip earthquakes are investigated in this study. The phases of the tidal shear stress for those new earthquakes are shown in Figure 5c; no correlation can be seen. The phases of the tidal shear stress for shallow dip-slip earthquakes, and the combined data set are shown in Figure 5d; once again, the correlation is not statistically significant. Therefore, I conclude that the previously 


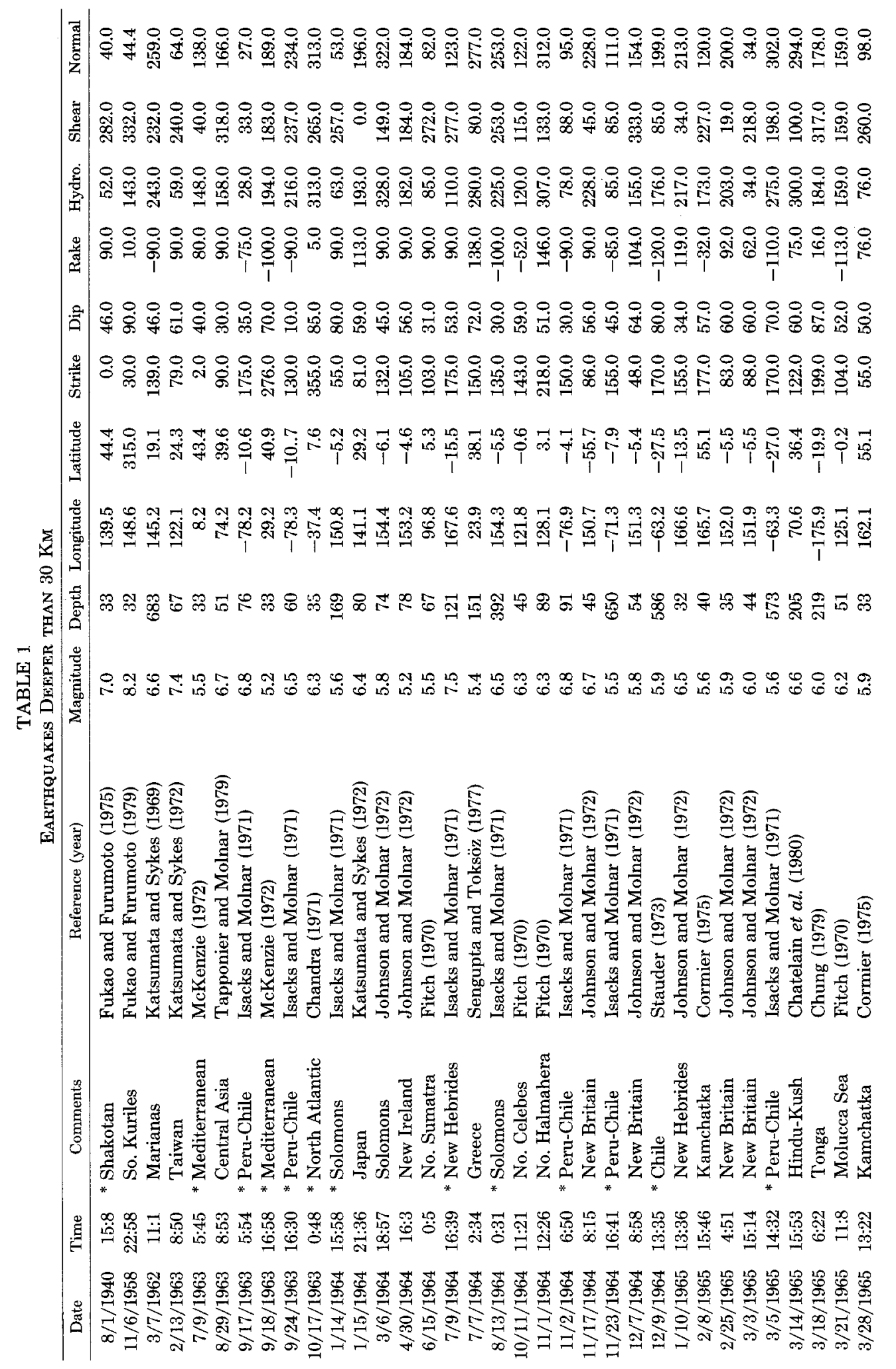




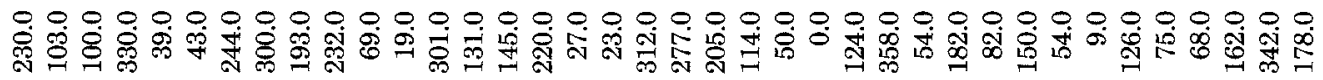

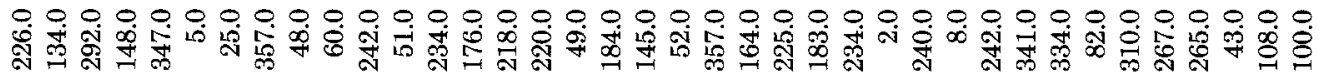

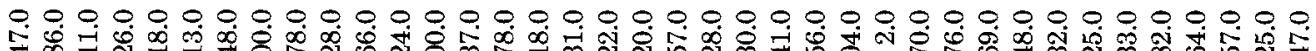

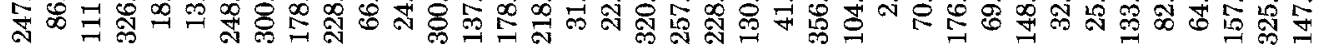

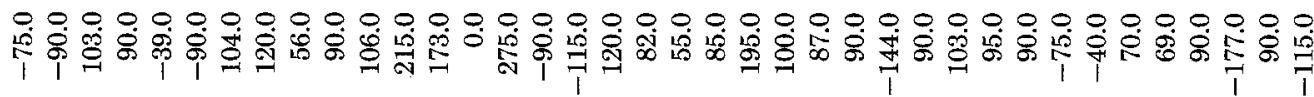

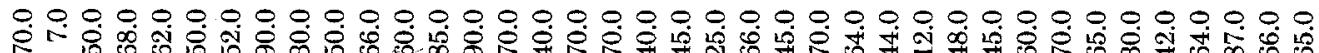

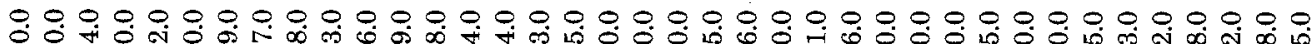

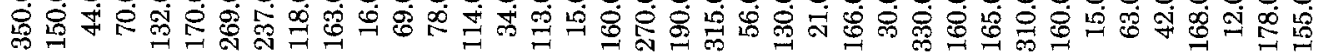

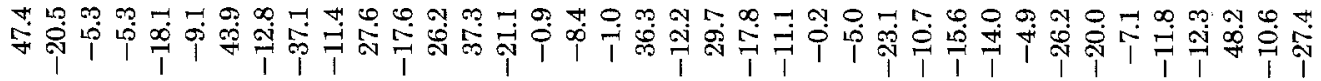

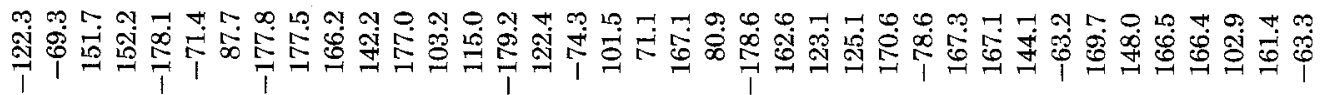

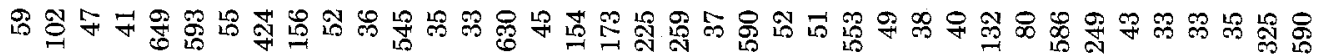
19

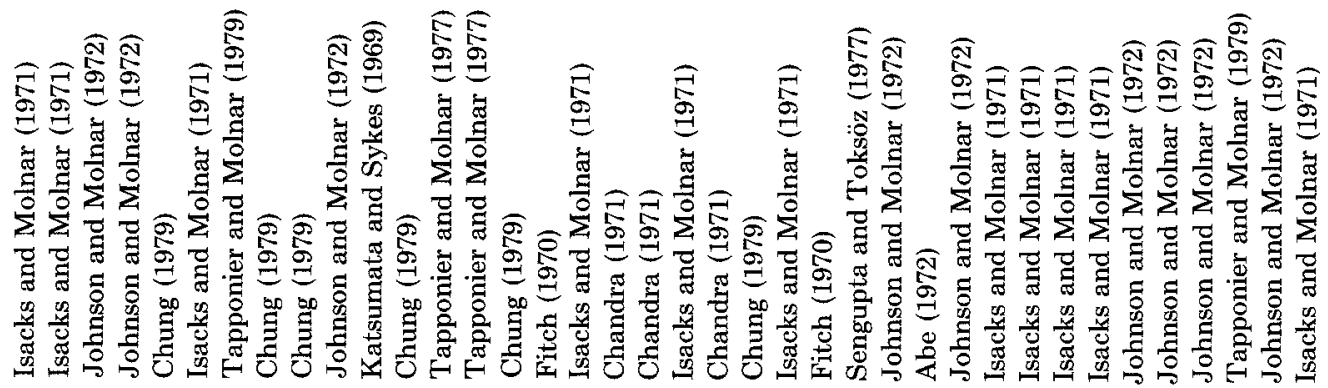

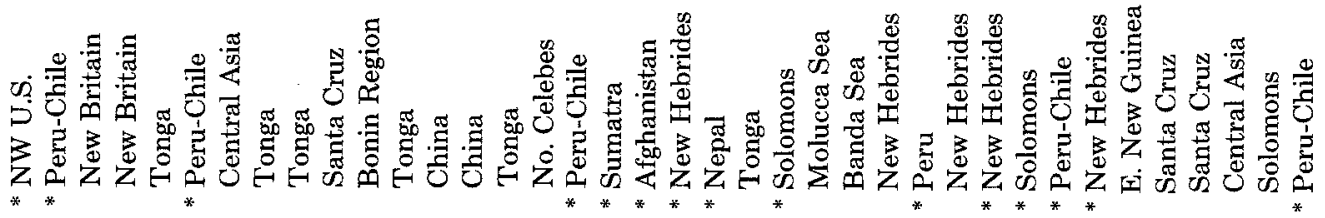

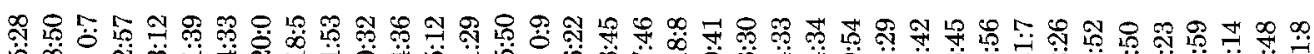

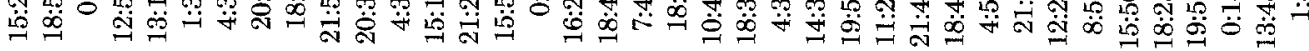

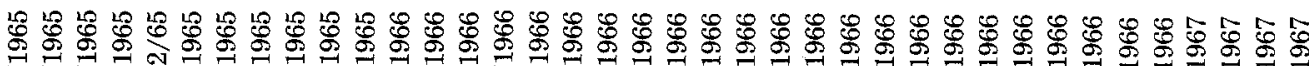

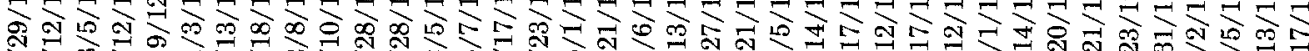

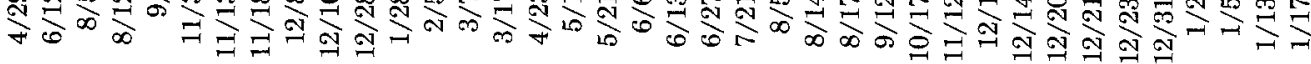




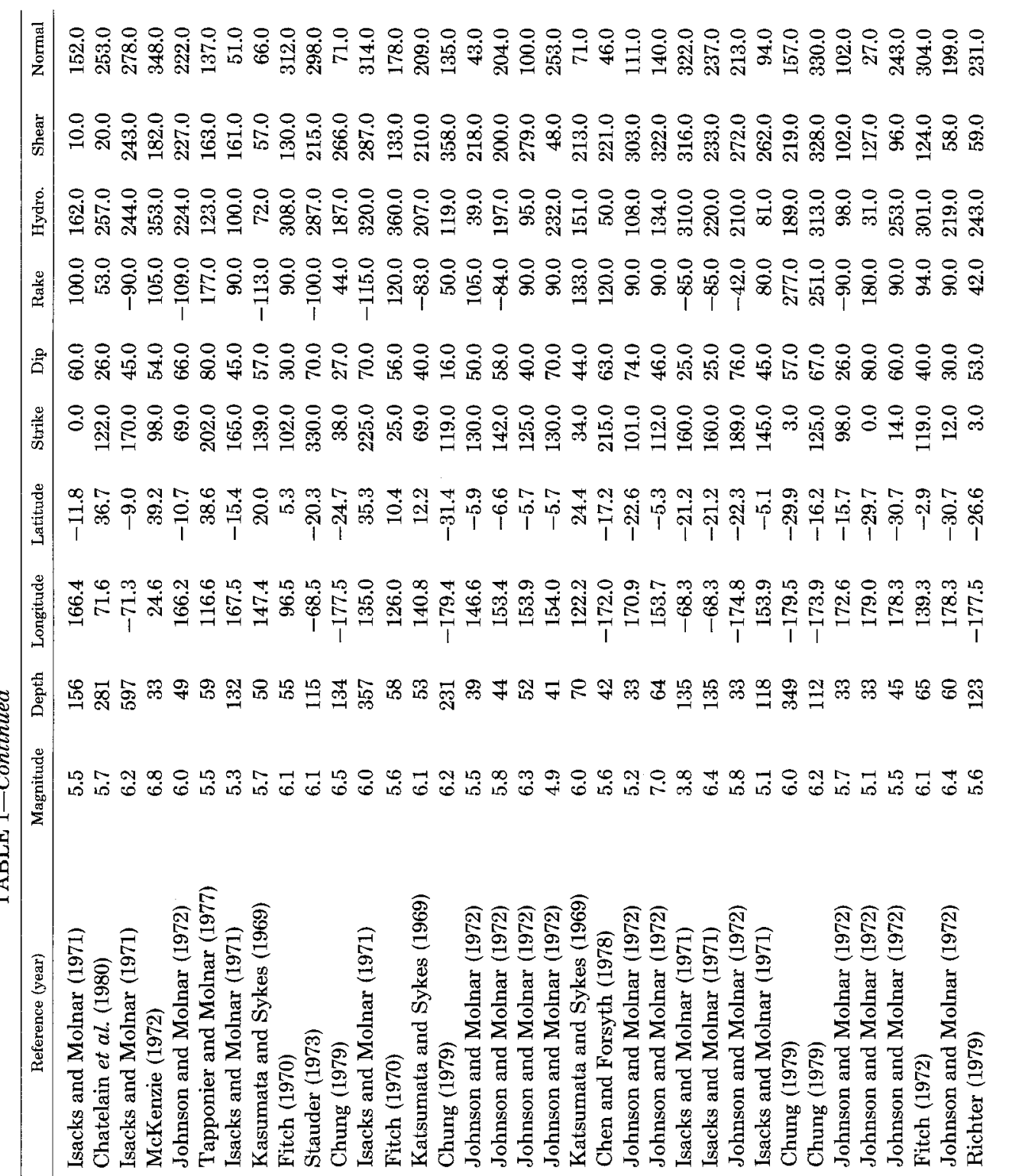

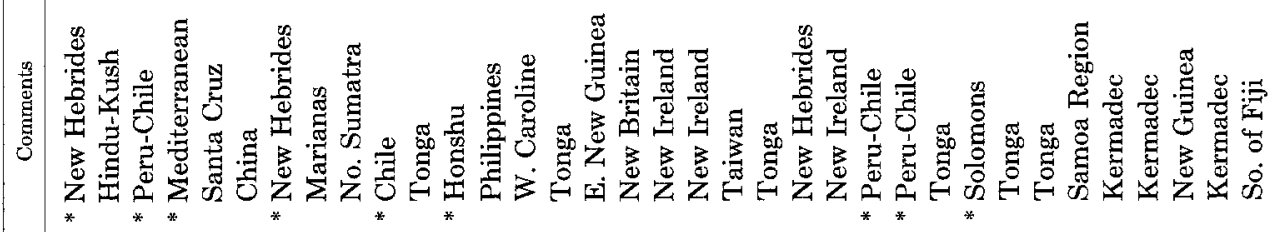

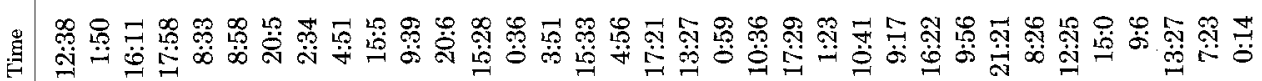

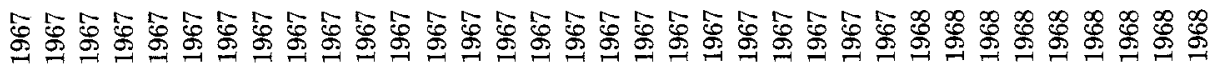

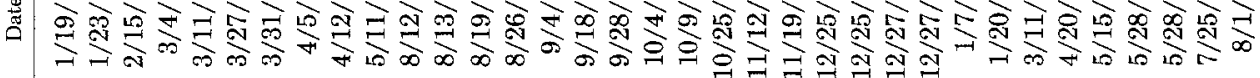




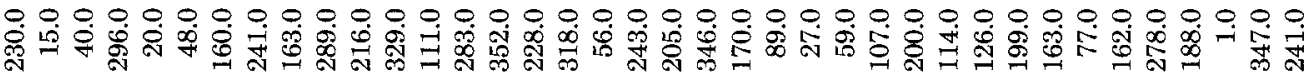

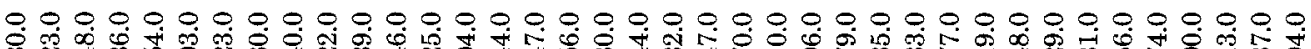

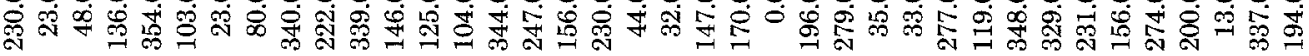

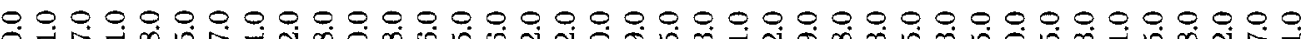

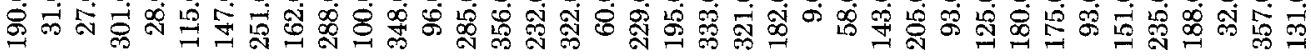

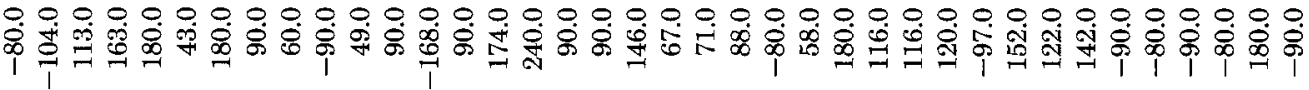

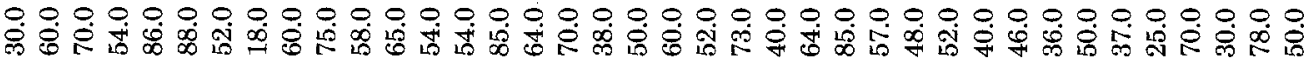

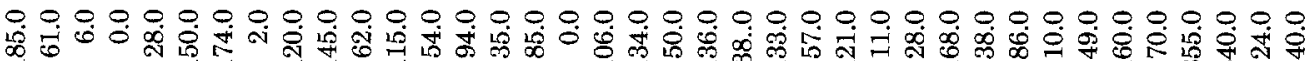

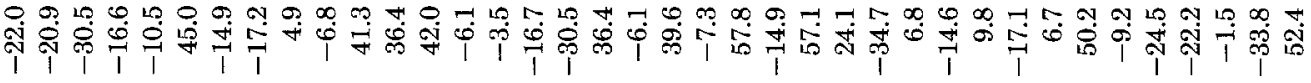
๓

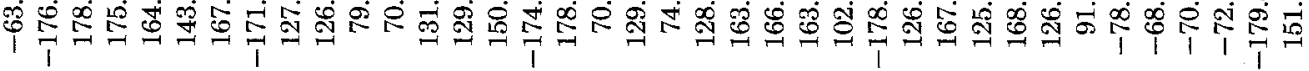

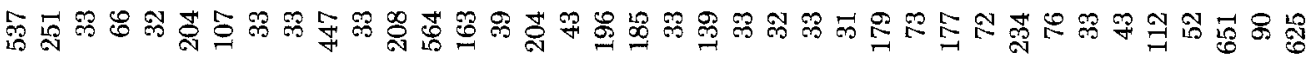
舟
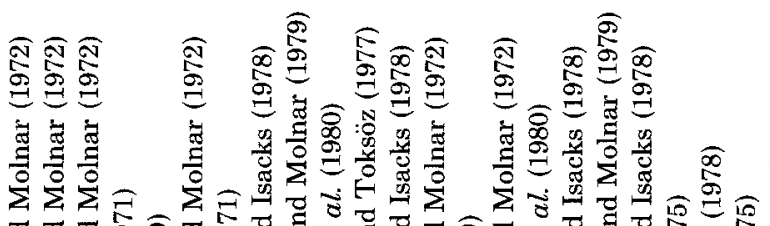

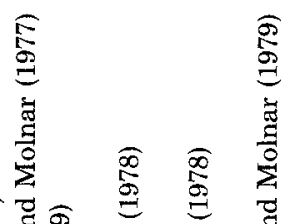

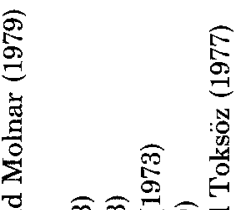

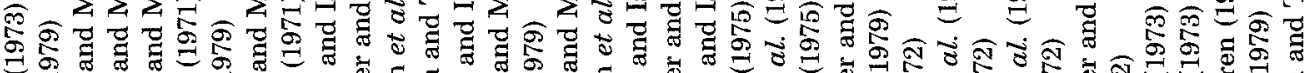

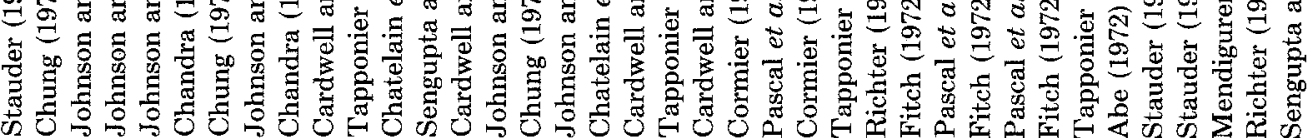

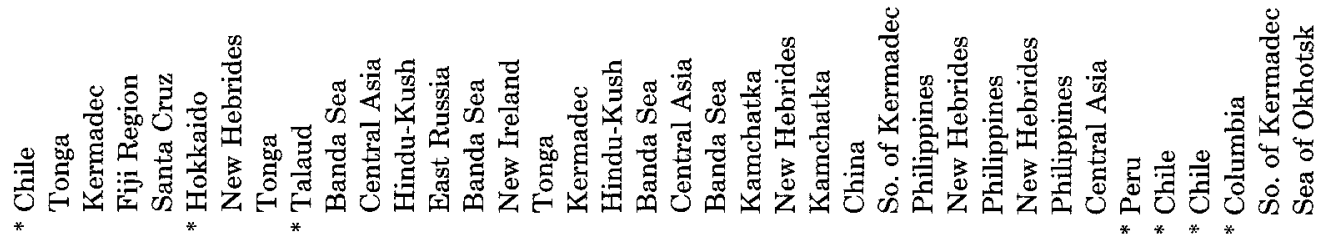
फ \&

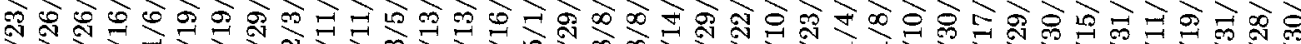

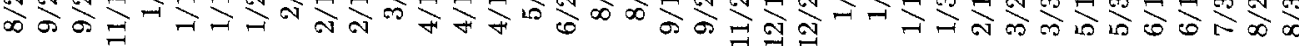




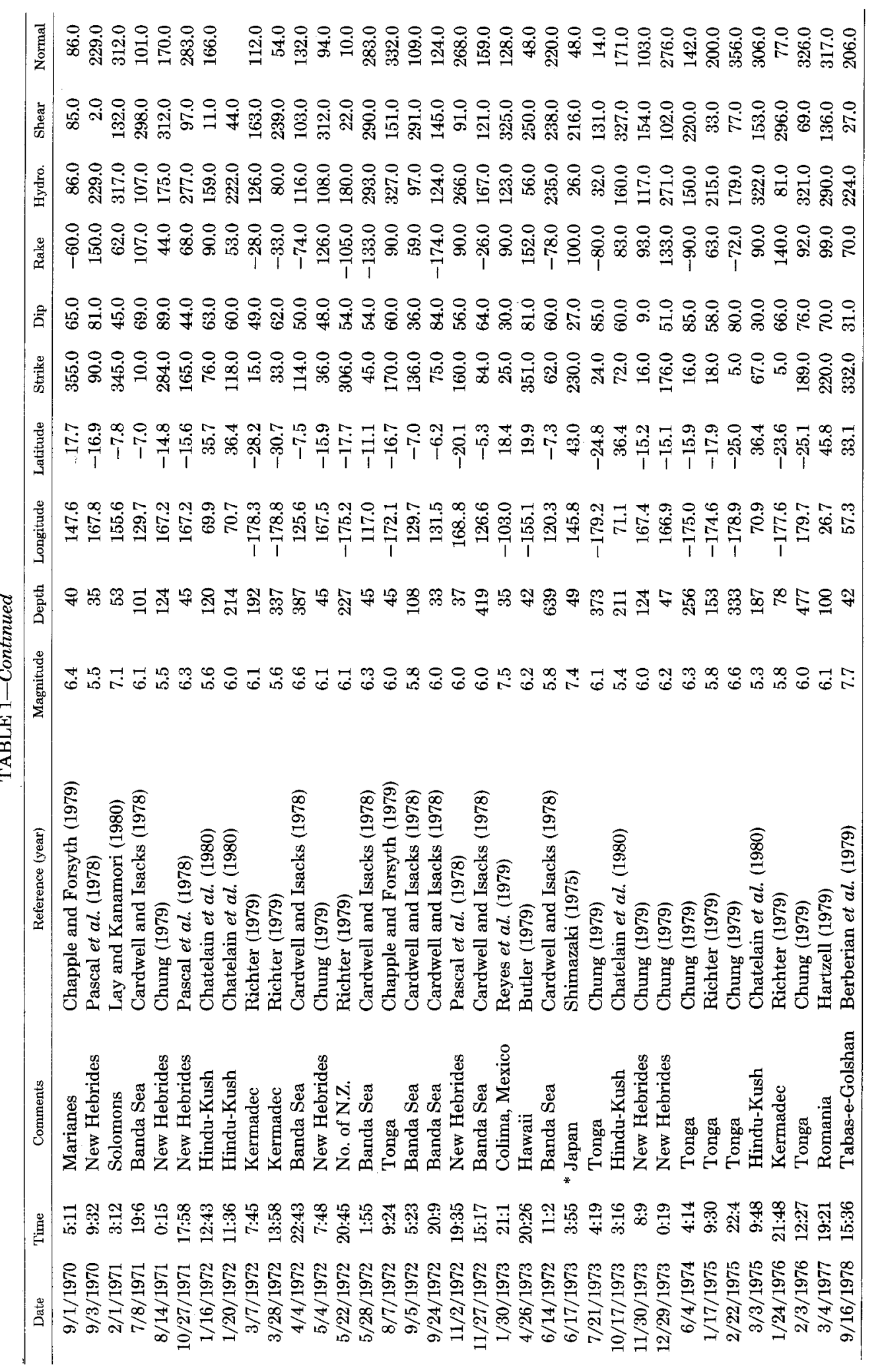


noted correlation between tidal shear stress and the origin times of shallow dip-slip earthquakes is not reproducible.

\section{Discussion}

Is there a simple relationship between solid earth tidal shear stress and the origin times of shallow dip-slip earthquakes as I suggested in my previous study? This is the primary question addressed in this paper, and the answer clearly seems to be no. This conclusion raises two other questions for which the answers are more

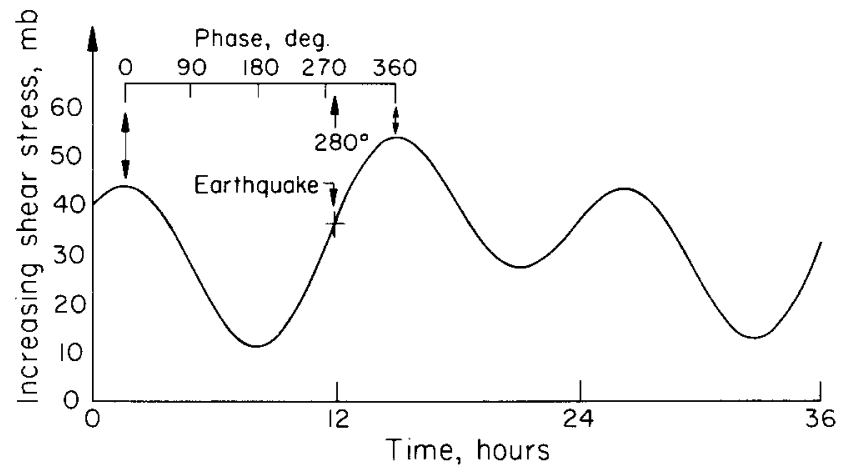

FIG. 2. Example of how earthquakes are assigned a phase relative to tidal stress time history.

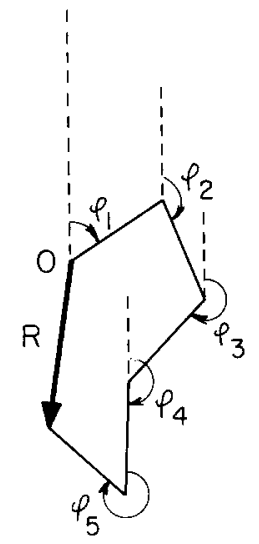

$$
\begin{gathered}
R=\sqrt{\left(\sum_{i=1}^{m} \sin \varphi_{i}\right)^{2}+\left(\sum_{i=1}^{m} \cos \varphi_{i}\right)^{2}} \\
P_{R} \approx \exp \left(-\frac{R^{2}}{m}\right)
\end{gathered}
$$

FIG. 3. Geometric interpretation of $P_{R}$, the probability that a random walk consisting of $m$ unit steps will traverse a distance of $R$ or greater.

ambiguous. The first is: how did my previous study manage to be so misleading? The second is: are the origin times of earthquakes ever affected by tidal stresses?

With regard to the first question, I believe that I made two mistakes, both of which I hope that this paper remedies. The first mistake, if it can be called that, was a lack of followthrough. That is, after calculating tidal phases for all earthquakes, I noticed that a pattern was present if the data set was grouped in a particular manner. Although this grouping formed the basis for a hypothesis, it did not constitute proof of its reality. The second mistake is related to the first. In my earlier 


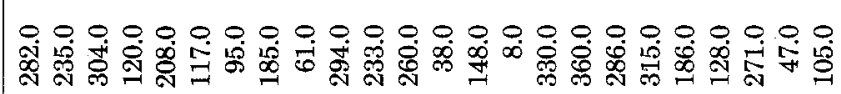

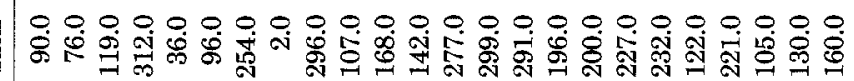

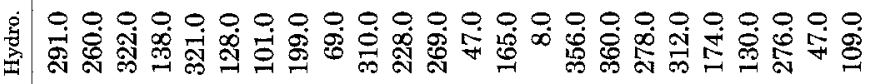

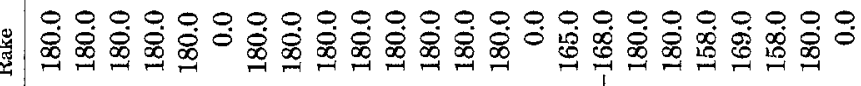
娄

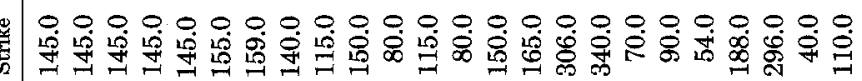

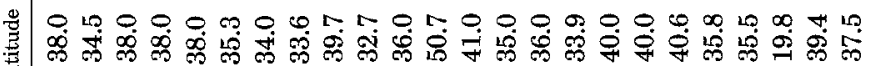

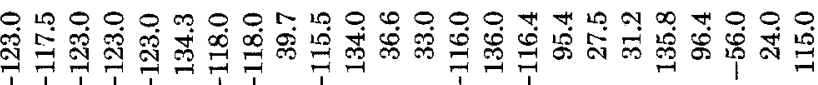

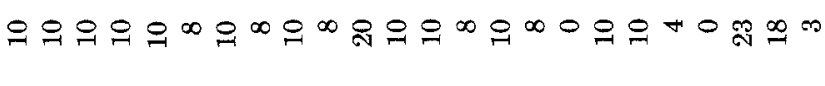

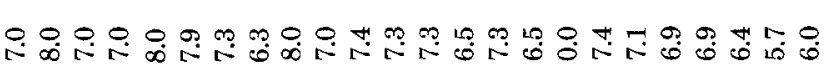

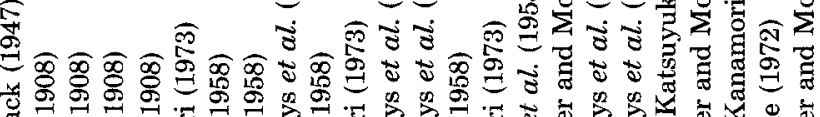

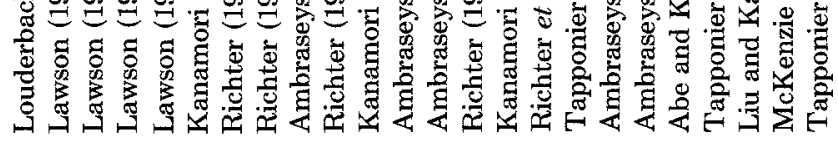

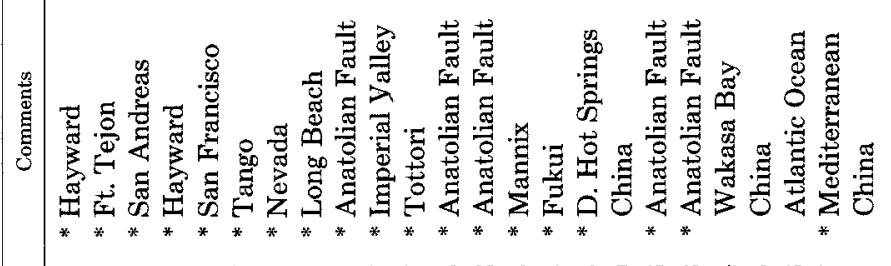

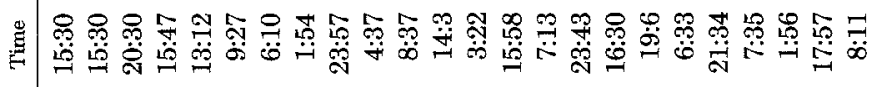

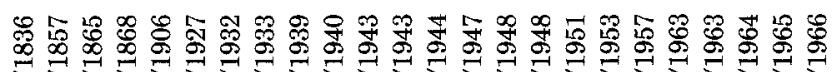

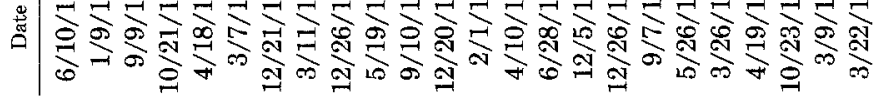




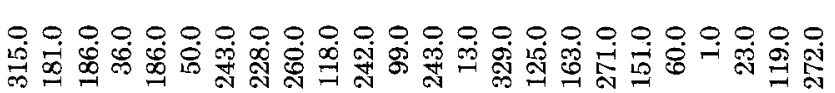

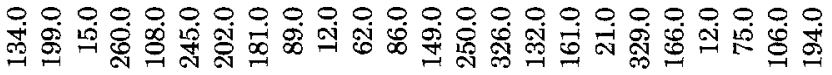

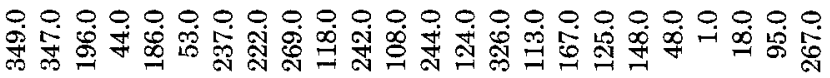

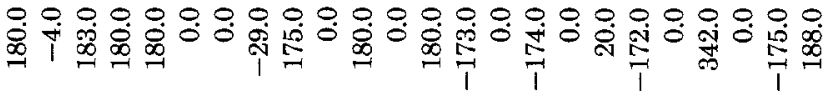

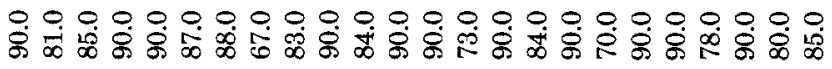

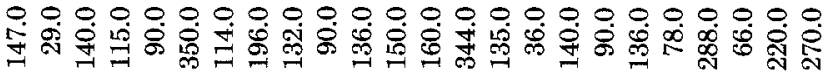

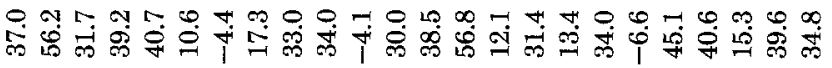
0 舟

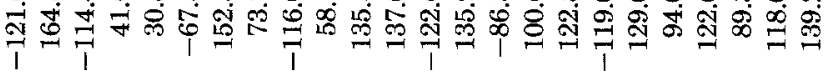

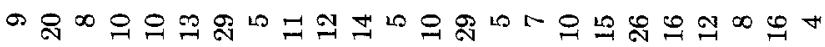

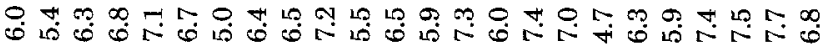

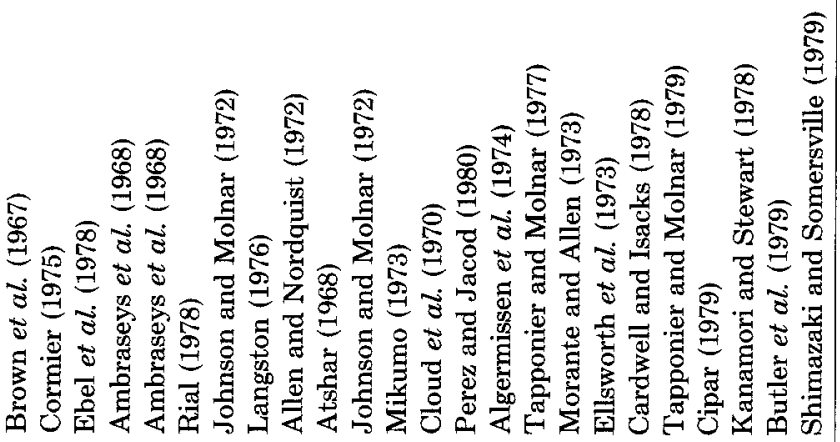

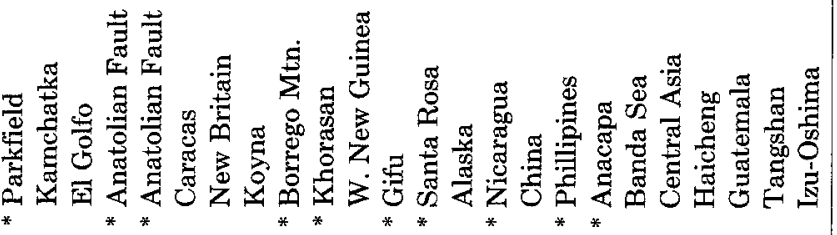

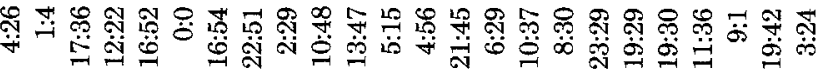

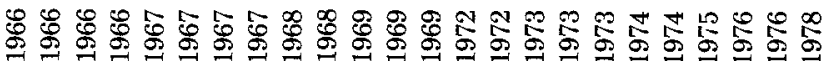
舟

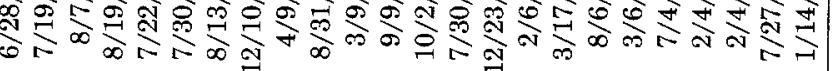




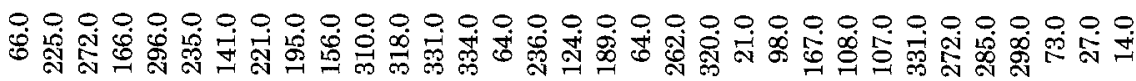

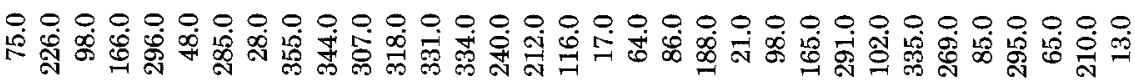

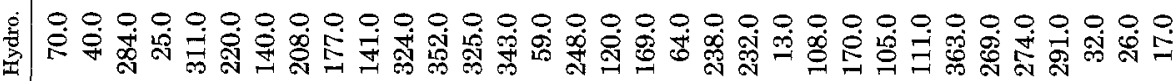

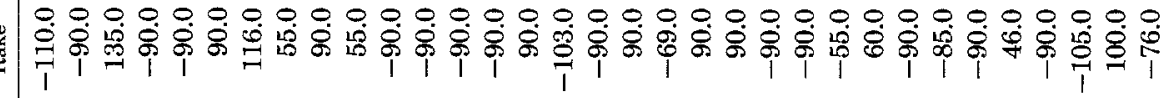

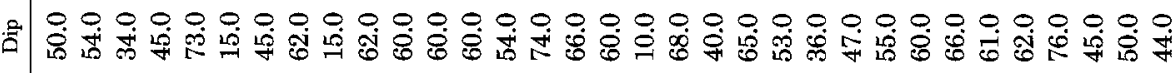

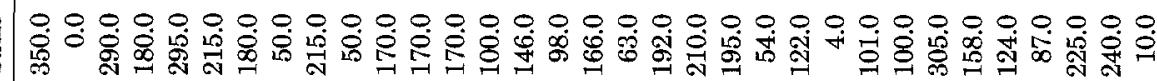

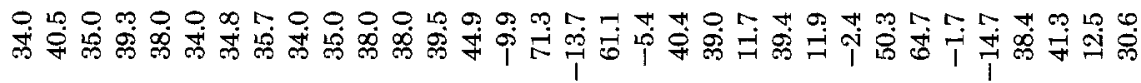

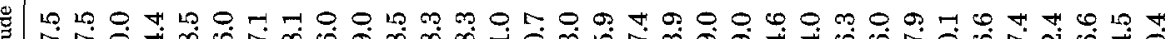

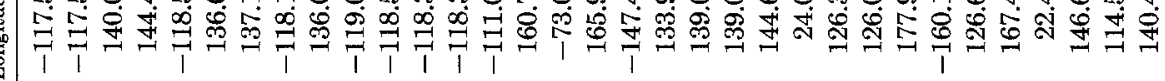

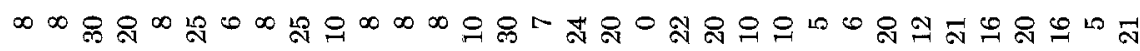

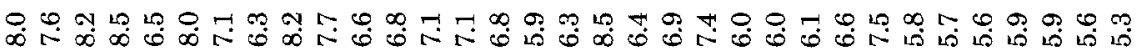

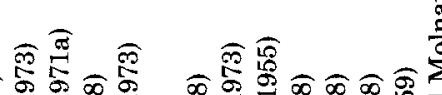

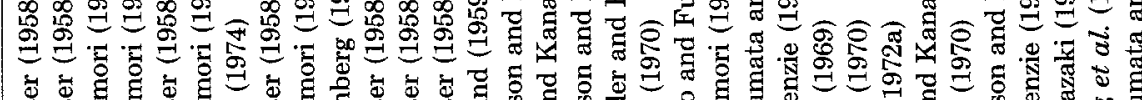

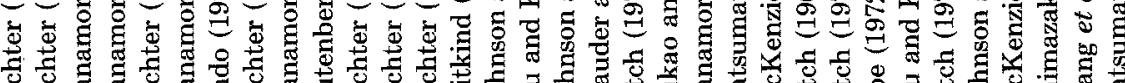

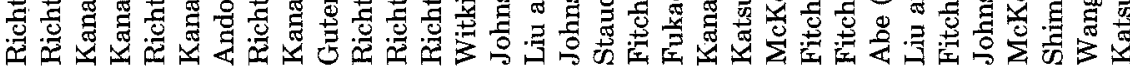

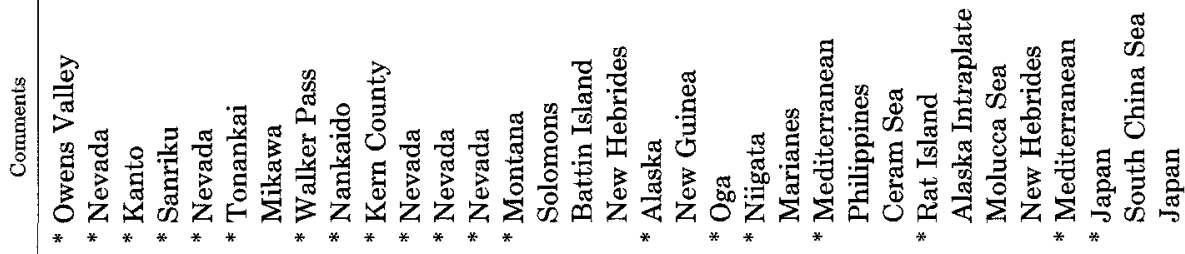

舟员品 $\bar{\infty}$

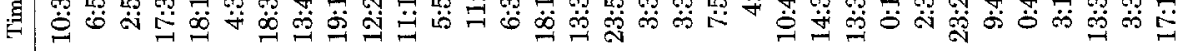

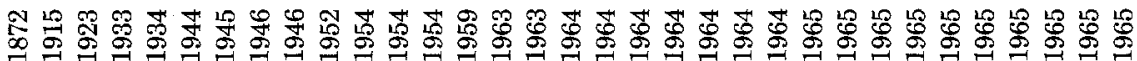

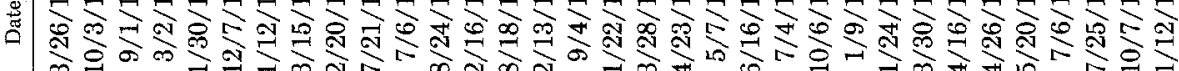




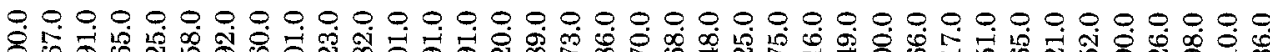

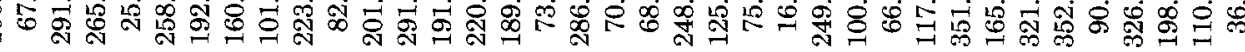

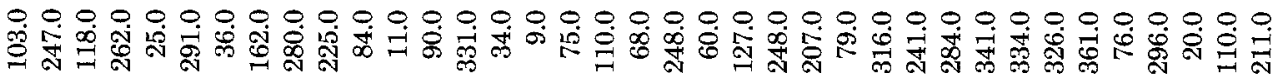

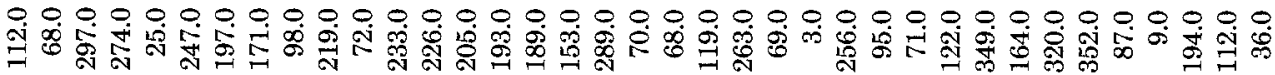
0000000000000000000000000000000000000

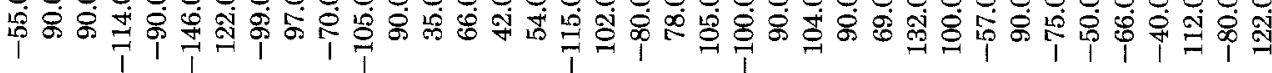

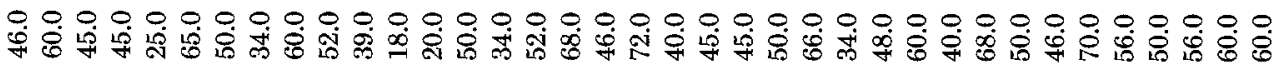

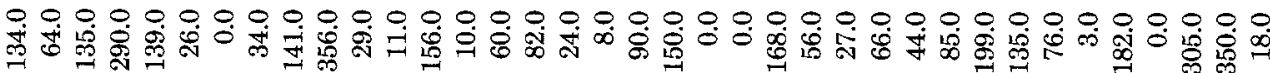

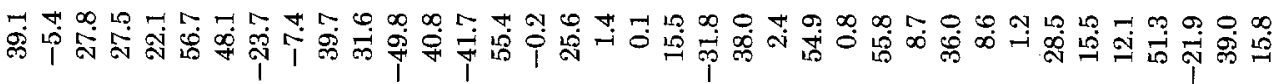

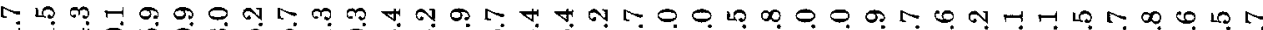

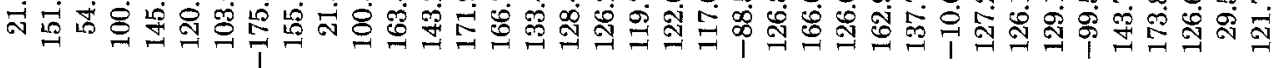

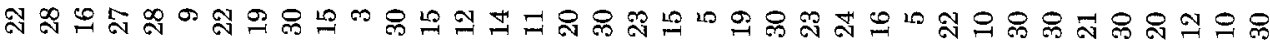

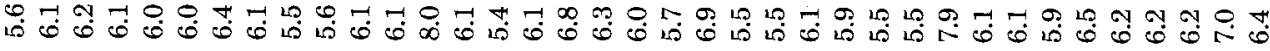
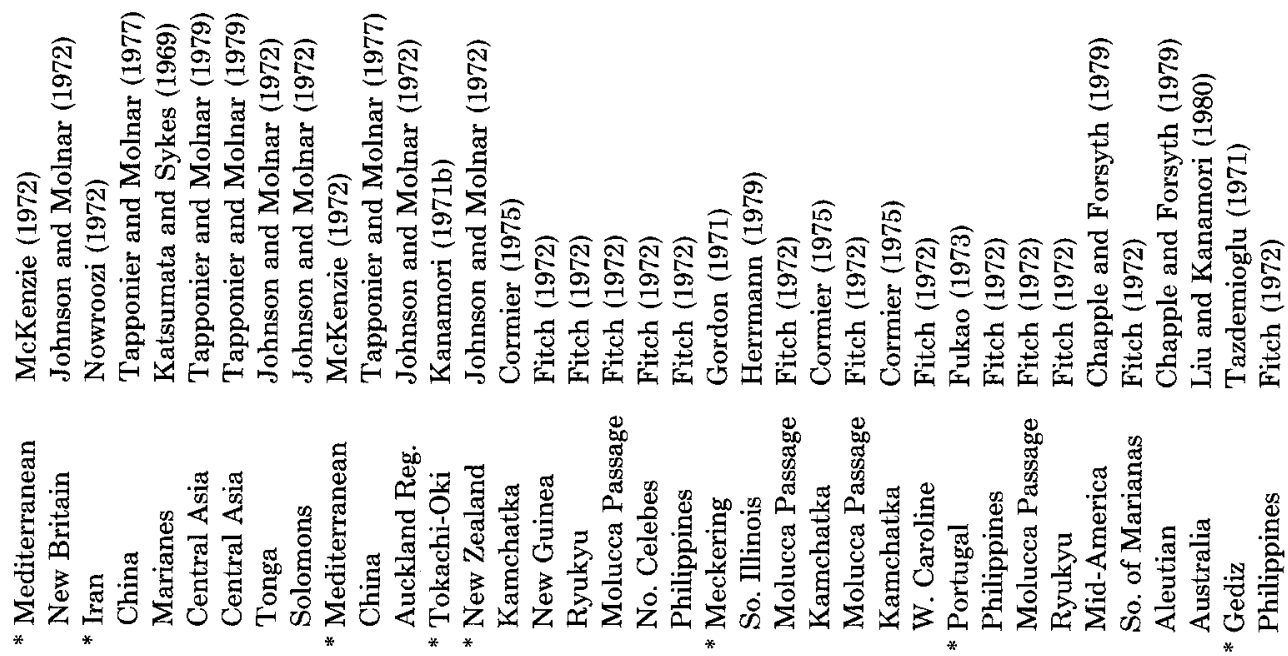

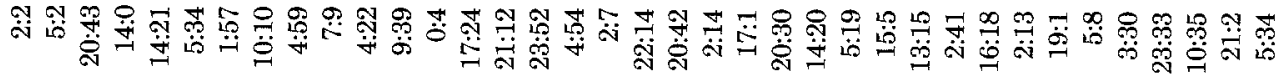

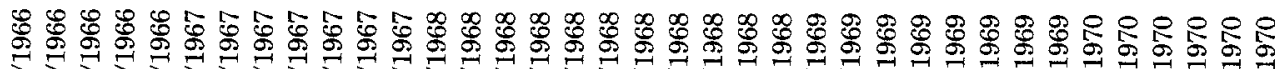

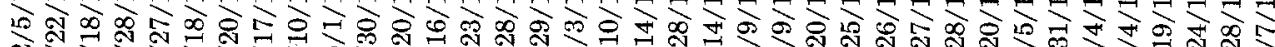

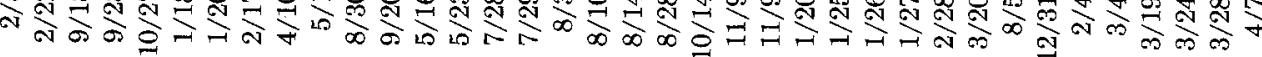




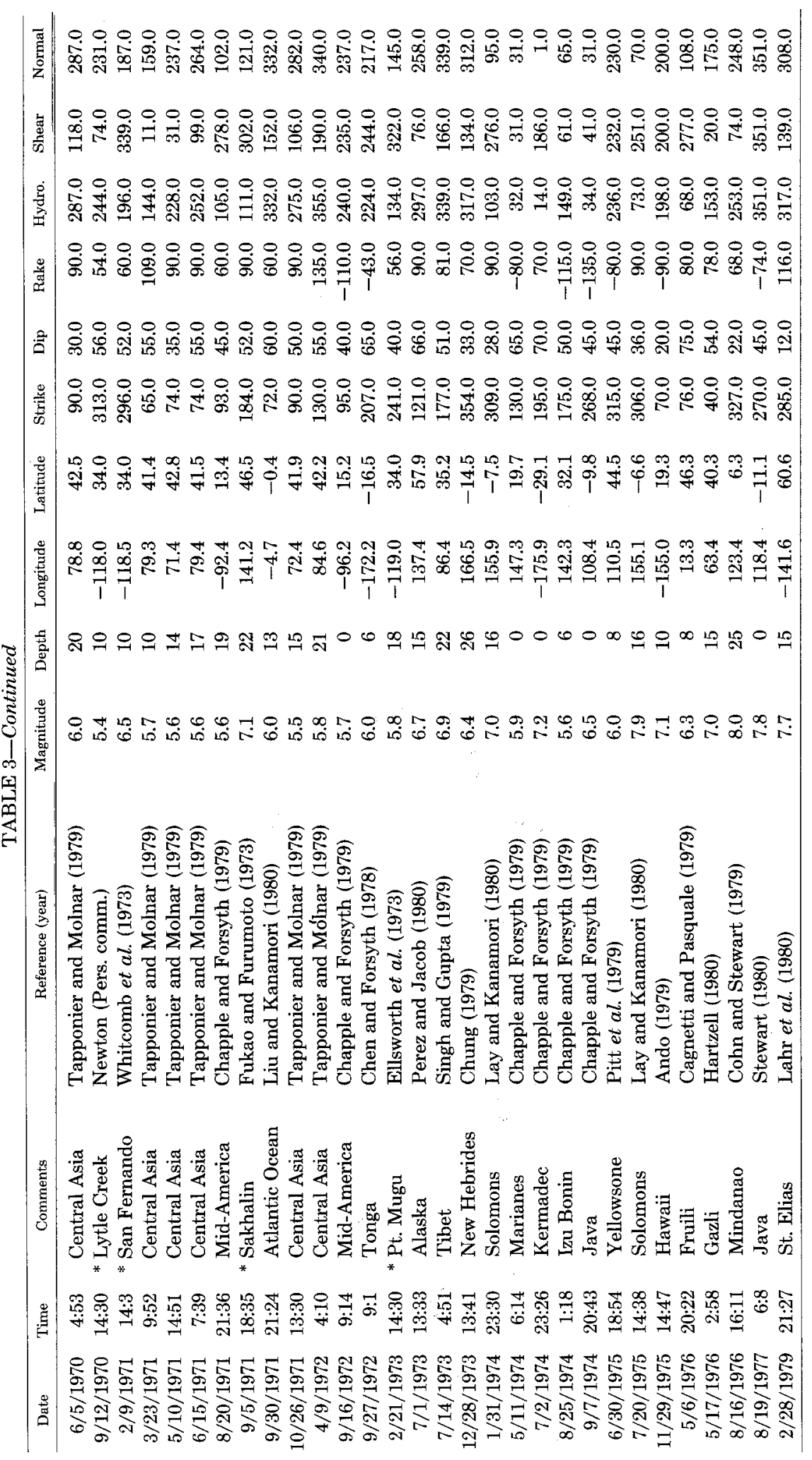


study, I employed the same statistical analysis as that used in this study. Although this analysis is simple and straightforward, I believe that it was incorrect to apply it to the case where the test for significance was conducted after a pattern in the data was recognized. For example, one can often devise a system for winning games of chance simply by observing patterns in the play. Although the system may appear
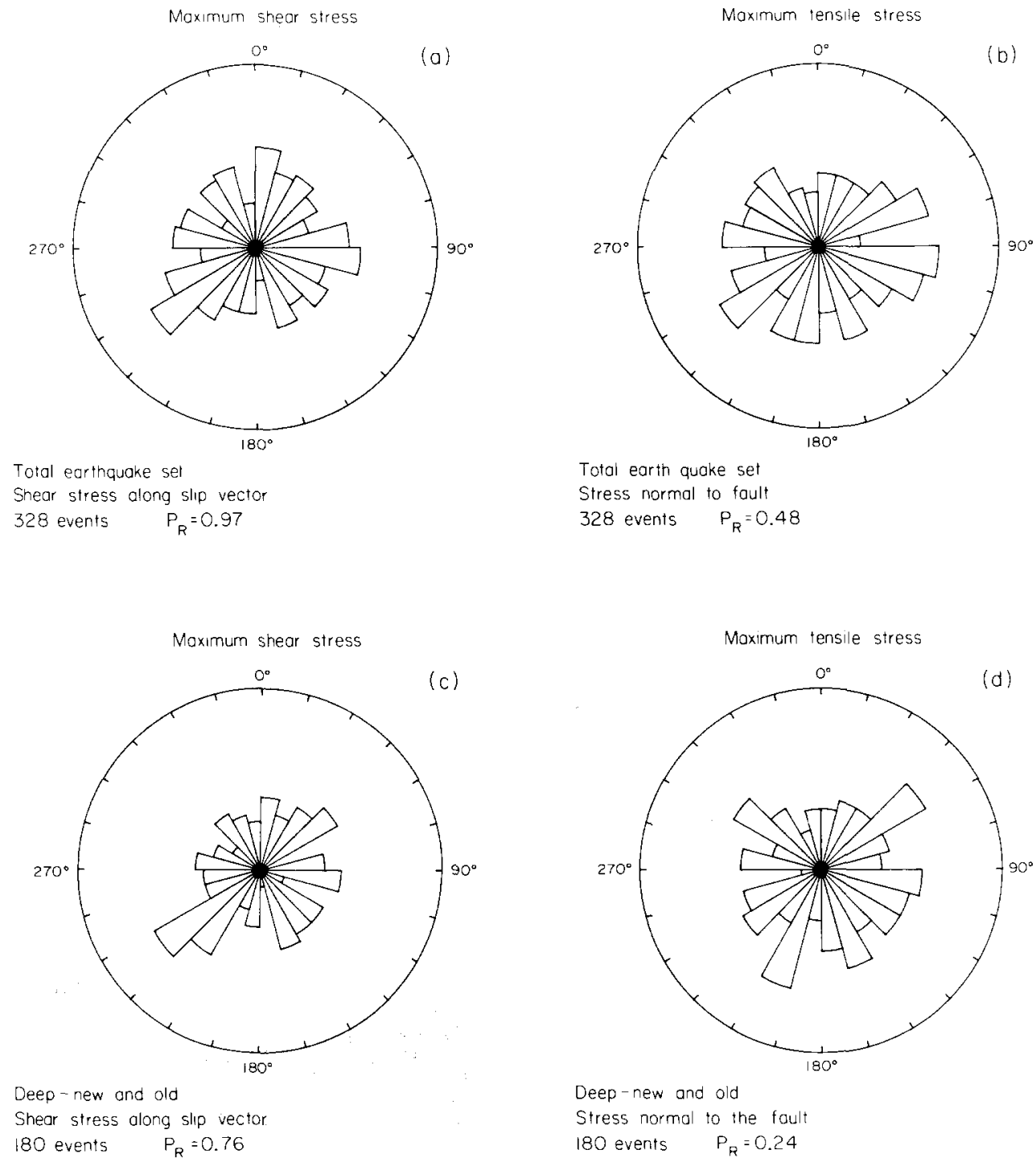

FIG. 4. Tidal phases of earthquakes. (a) Phases of tidal shear stress for entire data set. (b) Phases of tidal normal-to-the-fault compressive stress for entire data set. (c) Phases of tidal shear stress for all earthquakes deeper than $30 \mathrm{~km}$. (d) Phases of tidal normal-to-the-fault compressive stress for all earthquakes deeper than $30 \mathrm{~km}$.

to be foolproof (i.e., statistically significant), use of the system with one's own money may result in unpleasant consequences (e.g., writing this paper). Actually this problem seems to be very common in tidal triggering studies as well as in earthquake prediction studies. We see a pattern and then ask what the probability is that this pattern would arise in a random group of numbers. It has become painfully clear 
that we are far better at "predicting" earthquakes after their occurrence than before. Unless the question is well posed and strictly defined before any data are examined, statistical analysis of those data is likely to produce misleading results.

Unfortunately, this study does not provide a definite answer to the question of
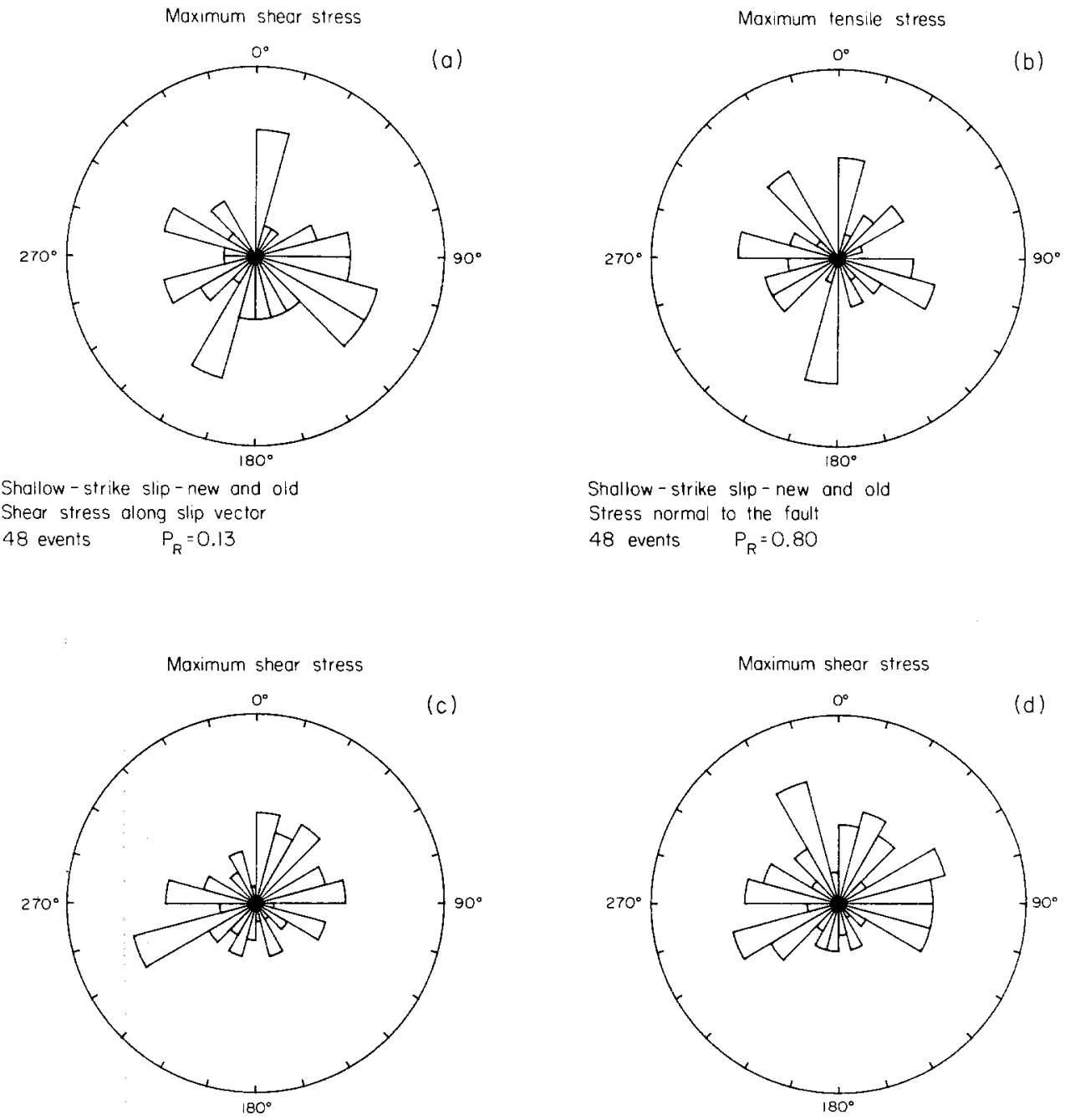

Shallow-dip stip-new sample

Shear stress along slip vector

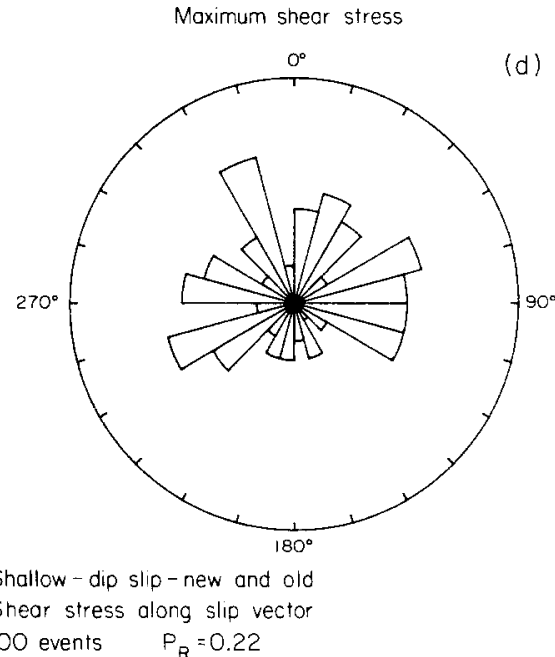

68 events

$P_{R}=0.79$

100 events $\quad P_{R}=0.22$

Fig. 5. Tidal phases of earthquakes. (a) Phases of tidal shear stress for all shallow strike-slip earthquakes. (b) Phases of tidal normal-to-the-fault compressive stress for all shallow strike-slip earthquakes. (c) Phases of tidal shear stress for shallow dip-slip earthquakes not included in the previous study (Heaton, 1975). (d) Phases of tidal shear stress for all shallow dip-slip earthquakes.

whether or not earthquake origin times are affected by tidal stresses. It merely shows that a simple correlation between origin times and simple calculations of solid earth tidal stresses is not seen for this data set. Some of the more convincing evidence for tidal triggering comes from investigations of earthquake swarms (Sauk, 1975 ; Klein, 1976a, b). In these studies, tidal periodicities are reported for swarms in 
several localities. Although periodicities are seen, the phase relationship for these correlations seems to change from one sequence to another. Klein (1976a) suggests that one mechanism for this phase shift may be the diffusion of pore fluids caused by tidal stresses. If this mechanism is important, details of fluid diffusion in fault zones must be understood before the times at which tidal stresses are most likely to trigger individual earthquakes can be calculated. Unfortunately, this type of analysis does not seem possible for the type of data sample considered in this study. Without such analysis, though, it does not seem possible to exclude tidal triggering for earthquakes of the type used in this study. Furthermore, studies of foreshock occurrence for large earthquakes by Jones and Molnar (1979) and by von Seggern et al. (1981) both show that somewhat higher levels of foreshock activity have occurred about $12 \mathrm{hr}$ prior to the large main shocks. One speculation is that this may be a manifestation of tidal triggering.

In conclusion, analysis of the tidal stress tensor for 222 earthquakes with known focal mechanisms fails to support my previous hypothesis (Heaton, 1975) that the origin times of shallow dip-slip earthquakes correlate with tidal shear stress. The application of statistical analysis to test for the statistical significance of patterns that are recognized after the data are inspected can often lead to misleading results.

\section{ACKNOWLEDGMENTS}

I thank Marcia McNutt, Bruce Julian, and Fred Klein for critically reviewing the manuscript. I also thank Karen Richter Canto and Gary M. Gutierrez for their work in computing and compiling the tidal phases of the earthquakes used in this study.

\section{REFERENCES}

Abe, K. (1972a). Mechanisms and tectonic implications of the 1966 and 1970 Peru earthquakes, Phys. Earth Planet. Interiors 5, 367-379.

Abe, K. (1972b). Lithospheric normal faulting beneath the Aleutian trend, Phys. Earth Planet. Interiors 5, 190-198.

Abe, K. (1974). Fault parameters determined by near- and far-field data: the Wakasa Bay earthquake of March 26, 1963, Bull. Seism. Soc. Am. 64, 1369-1382.

Algermissen, S. T., J. W. Dewey, C. J. Langer, and W. H. Dillinger (1974). The Managua, Nicaragua, earthquake of December 23, 1972; location, focal mechanism and intensity distribution, Bull. Seism. Soc. Am. 64, 993-1004.

Allen, C. R. and J. M. Nordquist (1972). Foreshock, main shock, and larger aftershocks of the Borrego mountain earthquake. U. S. Geol. Surv. Profess. Paper 787.

Ambraseys, N. N., A. Zatopek, M. Tasdemiroglu, and A. Aytun (1968). The Modurnu Valley earthquake of 22 July 1967, Unesco Ser. No. 622/BMS, RD/AVS, Paris, France.

Ando, M. (1974). Faulting in the Mikawa earthquake of 1945, Tectonophysics 22, 173-186.

Ando, M. (1979). Hawaii earthquake of November 29, 1975: low dip angle faulting due to forceful injection of magma, J. Geophys. Res. 84, 7616-7626.

Atshar, H. K. (1968). Report on the Great Dasht-E-Bayaz Earthquake of August 31 and September 1, 1968, Publ. No. 46, Tehran University Press.

Beaumont, C. and J. Berger (1972). An analysis of tidal strain observations from the United States of America: I. The laterally homogeneous tide, Bull. Seism. Soc. Am. 65, 1613-1629.

Berberian, M., I. Asudeh, R. G. Bilham, C. H. Scholz, and C. Soufleris (1979). Mechanisms of the main shock and the aftershock study of the Tobas-E-Golshan earthquake of September 16, 1978: a preliminary report, Bull. Seism. Soc. Am. 69, 1851-1859.

Brown, R. D., J. G. Vedder, R. E. Wallace, E. F. Roth, R. F. Yerkes, R. O. Castle, A. O. Waananen, R. W. Page, and J. P. Eaton (1967). The Parkfield-Cholame California earthquakes of June-August 1966Surface geologic effects, water resources aspects, and preliminary seismic data, U.S. Geol. Surv. Profess. Paper 579.

Butler, R. (1979). Shear-wave travel times from SS, Bull. Seism. Soc. Am. 69, 1715-1732. 
Butler, R., G. S. Stewart, and H. Kanamori (1979). The July 27, 1976 Tangshan, China earthquake-A complex sequence of intraplate events, Bull. Seism. Soc. Am. 69, 207-220.

Cagnetti, V. and V. Pasquale (1979). The earthquake sequence in Friuli, Italy, 1976, Bull. Seism. Soc. Am. 69, 1797-1818.

Cardwell, R. K. and B. L. Isacks (1978). Geometry of the subducted lithosphere beneath the Banda Sea in eastern Indonesia from seismicity and fault plane solution, J. Geophys. Res. 83, 2825-2838.

Chandra, U. (1971). Combination of $P$ and $S$ data for determination of earthquake focal mechanism, Bull. Seism. Soc. Am. 61, 1655-1673.

Chapple, W. M. and D. W. Forsyth (1979). Earthquakes and bending of plates at trenches, J. Geophys. Res. 84, 6729-6749.

Chatelain, J. O., S. W. Roecker, D. Hatzfeld, and P. Molnar (1980). Microearthquake seismicity and fault plane solutions in the Hindu Kush region and their tectonic implications, J. Geophys. Res. 85, 1365-1387.

Chen, T. and D. W. Forsyth (1978). A detailed study of two earthquakes seaward of the Tonga Trench: implications for mechanical behavior of the oceanic lithosphere, J. Geophys. Res. 83, 4995-5003.

Chung, W. Y. (1979). Part I: variation of seismic source parameters and stress drop within a descending slab as revealed from body-wave pulse-width and amplitude analysis. Part II: a seismological investigation of the subduction mechanism of aseismic ridges. Ph.D. Thesis, California Institute of Technology, Pasadena.

Cipar, J. (1979). Source process of the Haicheng, China earthquake from observations of $P$ and $S$ waves. Bull. Seism. Soc. Am. 69, 1903-1916.

Cloud, W. K., D. M. Hill, M. E. Huffman, C. W. Jennings, T. V. McEvilly, R. D. Nason, D. V. Steinbrugge, J. D. Tucker, J. D. Unger, and T. D. Youd (1970). The Santa Rosa earthquake of October, 1969, Mineral Information Service 23, 43-63.

Cormier, V. F. (1975). Tectonics near the junction of the Aluetian and Kurile-Kamchatka Basin, Bull. Geol. Soc. Am. 86, 443-453.

Ebel, J. E., L. J. Burdick, and G. S. Stewart (1978). The source mechanism of the August 7, 1966 El Golfo earthquake, Bull. Seism. Soc. Am. 68, 1281-1292.

Ellsworth, W. L., R. H. Cambell, D. P. Hill, R. A. Page, R. W. Alewine, T. C. Hanks, T. H. Heaton, J. A. Hileman, H. Kanamori, B. Minster, and J. H. Whitcomb (1973). Point Mugu, California, earthquake of 21 February 1973 and its aftershocks, Science 182, 1127-1129.

Fitch, T. J. (1970). Earthquake mechanisms and island arcs tectonics in the Indonesian-Philippine region, Bull. Seism. Soc. Am. 60, 565-591.

Fitch, T. J. (1972). Plate convergence, transcurrent faults, and internal deformation adjacent to southeast Asia and the western Pacific, J. Geophys. Res. 77, 4432-4460.

Fukao, Y. (1973). Thrust faulting at a lithospheric plate boundary, the Portugal earthquake of 1969, Earth Planet. Sci. Letters 18, 205-216.

Fukao, Y. and M. Furumoto (1975). Mechanism of large earthquakes along eastern margin of Japan Sea, Tectonophysics 26, 247-266.

Fukao, Y. and M. Furumoto (1979). Stress drops, wave spectra and recurrence intervals of great earthquakes-Implications of the Etorofu earthquake of 1958 Nov. 6, Geophys. J. 57, 23-40.

Gordon, F. R. (1971). Faulting during the earthquake at Meckering, Western Australia; 14 October 1968, R. Soc. N. Z. Bull. 9, 85-93.

Gutenberg, B. (1955). Earthquakes in Kern County, California during 1952, Calif. Div. Mines Bull. 171, $165-171$.

Hartzell, S. (1979). Analysis of the Bucharest strong ground motion record for the March 4, 1977 Romanian earthquake, Bull. Seism. Soc. Am. 69, 513-530.

Hartzell, S. (1980). Faulting process of the May 17, 1976 Gazli, USSR earthquake, Bull. Seism. Soc. Am. 70, 1715-1736.

Heaton, T. H. (1975). Tidal Triggering of earthquakes, Geophys. J. 43, 307-326.

Herrmann, R. B. (1979). Surface wave focal mechanisms for eastern north american earthquakes with tectonic implications, J. Geophys. Res. 84, 3543-3552.

Isacks, B. and P. Molnar (1971). Distribution of stresses in the descending lithosphere from a global survey of focal mechanisms of mantle earthquakes, Rev. Geophys. Space Phys. 9, 103-174.

Johnson, T. and P. Molnar (1972). Focal mechanisms and plate tectonics of the southeast Pacific, $J$. Geophys. Res. 77, 5000-5031.

Johnson, C. and L. K. Hutton (1980). The October 15, 1979 Imperial Valley earthquake: a study of aftershocks and prior seismicity, U.S. Geol. Surv. Profess Paper (in press).

Jones, L. M. and P. Molnar (1979). Some characteristics of foreshocks and their possible relationship to earthquake prediction and premonitory slip on faults, J. Geophys. Res. 84, 3596-3608. 
Kanamori, H. (1971a). Seismological evidence for lithospheric normal faulting-The Sanriku earthquake of 1933, Phys. Earth Planet. Interiors 4, 289-300.

Kanamori, H. (1971b). Focal mechanism of Tokachi-Oki earthquake of May 16, 1968, Tectonophysics 12, $1-13$.

Kanamori, H. (1973). Mode of strain release associated with major earthquakes in Japan, Ann. Rev. Earth Planet. Sci. 1, 213-239.

Kanamori, H. and G. S. Stewart (1978). Seismological aspects of the Guatemala earthquake of February 4, 1976, J. Geophys. Res. 83, 3427-3434.

Katsumata, M. and L. R. Sykes (1969). Seismicity and tectonics of the western Pacific: Izu-MarianeCaroline and Ryukyu-Taiwan regions, J. Geophys. Res. 74, 5923-5948.

Klein, F. W. (1976a). Earthquake swarms and the semidiural solid earth tide, Geophys. J. 45, $245-295$.

Klein, F. W. (1976b). Tidal triggering of reservoir-associated earthquakes. Eng. Geol. 10, 197-210.

Lahr, J. C., C. D. Stephens, H. S. Hasegawa, and J. Boatwright (1980). Alaskan seismic gap only partially filled by February 28, 1979 earthquake, Science 207, 1351-1353.

Langston, C. A. (1976). A body wave inversion of the Koyna, India earthquake of December 10, 1967 and some implications for body wave focal mechanisms, J. Geophys. Res. 81, 2517-2529.

Lawson, A. C. (1908). The California earthquake of April 18, 1906, Report of the State Earthquake Investigation Commission, published by Carnegie Institute of Washington.

Lay, T. and H, Kanamori (1980). Earthquake doublets in the Solomon Islands, Phys. Earth Planet. Interiors 21, 283-304.

Liu, H. and H. Kanamori (1980). Determination of source parameters of midplate earthquakes from the waveforms of body waves, Bull. Seism. Soc. Am. 70, 1989-2004.

Louderback, G. D. (1947). Central California earthquakes of the 1830 's, Bull. Seism. Soc. Am. 37, 33-75.

McKenzie, D. (1972). Active tectonics of the Mediterranean region, Geophys. J. 30, 109-185.

Mendiguren, J. A. (1973). Identification of free oscillation spectral peaks 1970, July 31, Columbian deep shock using the excitation criterion, Geophys. J. 33, 281-321.

Mikumo, T. (1973). Faulting mechanism of the Gifu earthquake of September 9, 1969 and some related problems, J. Phys. Earth 21, 191-212.

Morante, E. M. and C. R. Allen (1973). Displacement on the Philippine fault during the Ragay Gulf earthquake of 17 March 1973, Geol. Soc. Am. Abstr. 5, 744 (October 1972-1973 Annual Meetings).

Nowroozi, A. A. (1972). Focal mechanism of earthquakes in Persia, Turkey, West Pakistan, and Afghanistan, and plate tectonics of the Middle East, Bull. Seism. Soc. Am. 62, 823-850.

Pascal, G., B. L. Isacks, M. Barazangi, and J. Dubois (1978). Precise relocations of earthquakes and seismotectonics of the New Hebrides Island arc, J. Geophys. Res. 83, 4957-4973.

Perez, O. J. and K. H. Jacob (1980). Tectonic model and seismic potential of the eastern Gulf of Alaska and Yakutaga seismic gap, Bull. Seism. Soc. Am. 70, 1595-1606.

Pitt, A. M., C. S. Weaver, and W. Spence (1979). The Yellowstone Park earthquake of June 30, 1975, Bull. Seism. Soc. Am. 69, 187-205.

Rayleigh, L. (1919). On the problem of random vibrations and of random flights in one, two, or three dimensions, Phil. Mag. J. Sci. 37.

Reyes, A., J. N. Brune, and C. Lomnitz (1979). Source mechanism and aftershock study of the Colima, Mexico earthquake of January 30, 1973, Bull. Seism. Soc. Am. 69, 1819-1840.

Rial, J. A. (1978). The Caracas, Venezuela earthquake of July 1967: a multiple-source event, J. Geophys. Res. 83, 5405-5414.

Richter, C. F. (1958). Elementary Seismology, W. H. Freeman and Company, San Francisco, 768 pp.

Richter, F. M. (1979). Focal mechanisms and seismic energy release of deep and intermediate earthquakes in the Tonga-Kermadec region and their bearing on the depth extent of mantle flow, J. Geophys. Res. 84, 6783-6795.

Richter, C. F., C. R. Allen, and J. M. Nordquist (1958). The Desert Hot Springs earthquakes and their tectonic environment, Bull. Seism. Soc. Am. 48, 315-337.

Sauk, W. A. (1975). The Brawley, California earthquake sequence of January, 1975, and triggering by earth tides, Geophys. Res. Letters 2, 506-509.

Sengupta, M. K. and M. Nafi Toksöz (1977). The amplitudes of $P$ waves and magnitude corrections for deep focus earthquakes, J. Geophys. Res. 82, 2971-2980.

Shimazaki, K. (1972). Focal mechanism of a shock at the northwestern boundary of the Pacific plate: extensional feature of the oceanic lithosphere and compressional feature of the continental lithosphere, Phys. Earth Planet. Interiors 6, 397-404.

Shimazaki, K. (1975). Nemuro-Oki earthquake of June 17, 1973: a lithospheric rebound at the upper half of the interface, Phys. Earth Planet. Interiors 9, 314-327.

Shimazaki, K. and P. Somerville (1979). Static and dynamic parameters of the Izu-Oshima, Japan 
earthquake of 14 January, 1978, Bull. Seism. Soc. Am. 69, 1343-1378.

Singh, D. D. and H. K. Gupta (1979). Source mechanism and surface-wave attenuation studies for Tibet earthquake of July 14, 1973, Bull. Seism. Soc. Am. 69, 737-750.

Stauder, W. (1973). Mechanism and spatial distribution of Chilean earthquakes with relation to subduction of the oceanic plate, J. Geophys. Res. 78, 5033-5061.

Stauder, W. (1976). Fault motion in the larger earthquakes of the Kurile-Kamchatka arc and of the Kurile-Hokkaido corner, J. Geophys. Res. 81, 297-308.

Stauder, W. and G. A. Bollinger (1966). The focal mechanism of the Alaska earthquake of March 28, 1964 and of its aftershock sequence, J. Geophys. Res. 71, 5283-5296.

Stewart, G. S. and S. N. Cohn (1979). The 1976 August 16, Mindanao, Philippine earthquake $\left(M_{S}=\right.$ 7.8)-Evidence for a subduction zone south of Mindanao, Geophys. J. 57, 51-65.

Tapponier, P. and P. Molnar (1977). Active faulting and tectonics in China, J. Geophys. Res. 82, 2905-2930.

Tapponnier, P. and P. Molnar (1979). Active faulting and Cenozoic tectonics of the Tien Shen, Mongolia, and Baykal regions, J. Geophys. Res. 84, 3425-3459.

Tasdemiroglu, M. (1971). The 1970 Gediz earthquake in Western Anatolia, Turkey, Bull. Seism. Soc. Am. 61, 1507-1529.

von Seggern, D., S. S. Alexander, and C. Baag (1981). Seismicity parameters preceding moderate to major earthquakes, J. Geophys. Res. 86, 9325-9329.

Wang, S., R. J. Geller, S. Stein, and B. Taylor (1979). An intraplate thrust earthquake in the south China Sea, J. Geophys. Res. 84, 5627-5631.

Whitcomb, J. H., C. R. Allen, J. D. Garmany, and J. A. Hileman (1973). San Fernando earthquake series, 1971: focal mechanisms and tectonics, Rev. Geophys. Space Phys. 11, 693-730.

Witkind, I. J. (1959). The Hebgen Lake, Montana, earthquake of August 17, 1959, U.S. Geol. Surv. Profess. Paper 435, 37-51.

U.S. Geological Survey

Seismological Laboratory, 252-21

California Institute of Technology

Pasadena, California 91125

Manuscript received 17 May 1982 